\title{
IDENTIFIKASI TINGKAT PARTISIPASI MASYARAKAT DALAM UPAYA PENINGKATAN KUNJUNGAN WISATA ALAM PANTAI TORONG BESI
}

\author{
Bonefansiana Dewi Endang ${ }^{1)}$, Siti Nuurlaily Rukmana ${ }^{2)}$ \\ 1)2) Program Studi Prencanaan Wilayah dan Kota, Fakultas Teknik \\ Universitas PGRI Adi Buana Surabaya \\ email: bonefansiana@gmail.com
}

\begin{abstract}
Abstrak
Pantai Torong Besi Kabupaten Manggarai dikembangkan sebagai salah satu daerah tujuan wisata baik untuk nusantara maupun mancanegara karena memiliki daya tarik untuk memikat pengunjung. Objek wisata ini mempunyai keindahan alam seperti pantai dengan pasir putih yang indah dan alam dengan tekstur yang berbukit. Sehingga mempunyai potensi untuk dikembangkan yang sangat besar. Tujuan dari penelitian ini untuk mengidentifikasikan karakteristik wilayah kawasan wisata pantai dan untuk mengetahui tingkat partisipasi masyarakat terhadap kawasan wisata pantai Torong Besi. Metode yang digunakan dalam penelitian ini adalah deskriptif kualitatif dan deskriptif kuantitatif. Metode pengumpulan data yang digunakan dalam penelitian ini yaitu observasi, wawancara, kuisioner, dan dokumentasi. Hasil dari penelitian ini adalah wisata pantai Torong Besi sudah layak untuk dijalankan mengingat wisata pantai Torong Besi mempunyai daya tarik untuk menarik minat pengunjung yang terdiri dari beberapa objek Gua Maria, Gereja Tua dan pasir putih. Untuk aksesbilitas menuju Wisata Pantai Torong Besi sudah cukup baik. Namun ada beberapa yang belum memenuhi standar seperti kondisi jalan yang kurang baik, jarak terminal dengan lokasi objek wisata yang terlalu jauh, dan jumlah penujuk jalan yang masih terbatas. Fasilitas di Wisata Alam Pantai Torong Besi sudah memadai. Perlu adanya penambahan terkait jumlah hotel, restoran atau rumah makan di sekitar lokasi Wisata, dan perlunya perbaikan pada fasilitas toilet. Pelayanan tambahan di objek Wisata Alam Pantai Torong Besi belum tersedia, karena pengelolaanya masih bergantung kepada masyarakat. Upaya partisipasi yang dilakukan oleh masyarakat yaitu di dominasi citizen control sebesar $82 \%$.
\end{abstract}

Kata Kunci : Partisipasi Masyarakat, Pariwisata, Peningkatan Kunjungan

\begin{abstract}
Torong Besi Beach, Manggarai Regency has an attraction to be developed as a tourist destination for both domestic and foreign tourists. This tourist attraction has enormous potential to be developed, such as the natural charm of a very beautiful beach with white sand and hilly natural textures. This study aims to identify the characteristics of the coastal tourism area and to determine the level of community participation in the Torong Besi beach tourism area. The method used in this research is descriptive qualitative and descriptive quantitative. Data collection methods used in this study are observation, interviews, questionnaires, and documentation. The results of this study are to determine the characteristics of the tourist area of Torong Besi Beach and the level of community participation in the natural coastal tourism area. The attractiveness of the analysis results obtained that Torong Besi Beach Tourism is feasible to run. The accessibility to Torong Besi Beach Tourism is quite good. However, there are some that do not meet the standards such as poor road conditions, the distance between the terminal and the tourist attraction location that is too far away, and the number of road pointers is still limited. The facilities at Torong Besi Beach Nature Tourism are adequate. There needs to be an increase in the number of hotels, restaurants or restaurants around the tourist site, and the need for improvements to toilet facilities. Additional services at the Torong Besi Beach Nature Tourism object are not yet available, because the management still depends on the community.

Keywords : Community Participation, Tourism, Increased Visits
\end{abstract}




\section{PEndahuluan}

Pariwisata sebagai penggerak pertumbuhan ekonomi dan kesejahteraan berperan penting dalam hal pembangunan disuatu daerah dan bagian tak terpisahkan dari kehidupan manusia. Pengembangan wisata merupakan suatu bentuk upaya untuk mengembangkan potensi wisata agar lebih menarik minat wisatawan. (Bareto dan Giantari, 2015). Partisipasi masyarakat dalam upaya peningkatan kunjungan wisata sangat penting. Masyarakat harus berperan aktif dan bertanggung jawab untuk meningkatkan perekonomian dan mutu hidup masyarakat dan dalam meningkatkan perekonomian dan mutu hidup, pembangunan yang dilakukan sudah sesuai harapan. Partispasi dalam pengembangan pariwisata mampu meningkatkan rasa memiliki terhadap masyarakat dalam setiap progam yang dirancang mampu mengendalikan pengembangan arah kebijakan (Raharjana, 2016).

Wisata alam Pantai Torong Besi salah satu tujuan dari wisata di Manggarai yang letaknya di Reo. Wisata Alam Pantai Torong Besi sendiri sudah dikenal banyak orang, Pantai Torong Besi mengalami peningkatan kunjungan wisatawan hanya pada hari libur karena tidak mendukungnya aksesbilitas, fasilitas, dan pelayanan lainnya, yang dapat memenuhi kebutuhan wisatawan pantai torong besi menyebabkan wisatawan belum tertarik untuk berkunjung ke Pantai Torong Besi, padahal sampai saat ini retribusi masih gratis.

Partisipasi masyarakat setempat belum bisa meningkatkan pengunjung untuk berwisata ke Pantai Torong Besi. Hal tersebut karenakan minimnya pengetahuan warga masyarakat setempat mengenai parawisata karena rendahnya sumber daya manusia. Selain itu Matapencaharian masyarakat setempat yang didominasi pada sektor pertanian mengurangi minat masyarakat di sektor parawisata. Untuk mengembangkan kawasan wisata tidak terlepas dari keterlibatan dan partisipasi masyarakat disekitar objek wisata. Wisata Alam Torong Besi sendiri sudah masuk dalam peruntukan pariwisata seperti yang tertuang dalam RTRW Kabupaten Manggarai Tahun 2012-2032, dan direncanakan untuk dijadikan destinasi pariwisata. Partisipasi masyarakat sekitar merupakan unsur pertama yang diperlukan dalam pelaksanaaan pengembangan wisata itu sendiri. Rendahnya partisipasi masyarakat salah satu penghambat kemajuan tempat wisata di Pantai Torong Besi. Tujuan dari penelitian ini adalah untuk mengidentifikasikan karakteristik Wisata Alam Pantai Torong Besi, serta mengetahui Tingkat Partisipasi Masyarakat terhadap Wisata Alam Pantai Torong Besi

\section{KAJIAN LITERATUR}

\section{a. Pengertian Pariwisata}

Secara etimologi kata "pariwisata" meruapakan bahasa yang berasal dari bahasa sansekerta. Pariwisata merupakan gabungan dari dua kata, "pari" artinya banyak, atau berkeliling serta "wisata" artinya berpergian. Jadi, dari kata tersebut dapat ditarik suatu kesimpulan mengenai pariwisata yaitu sebagai suatu perjalanan yang dilakukan berkali- kali dari suatu tempat ke tempat yang lain dengan maksud bukan untuk menetap atau bertempat tinggal didaerah tersebut dengan mencari nafka atau bekerja di tempat yang dikunjungi, tetapi semata-mata untuk menikmati perjalanan yang dilakukan tersebut guna kepuasan bertamasya dan berekreasi serta untuk memenuhi keinginan individu yang melaksanakannya.

Pariwisata merupakan perjalanan seseorang didalam kurun waktu yang hanya sesaat, dalam artian tidak menetap ke tempat diluar tempat tinggal atau tempat asal mereka dan meninggalkan segala rutinitas mereka seperti biasanya untuk melangsungkan hidup. (Morgenroth, 2016).

\section{b. Pengertian Partisipasi}

Banyak ahli memberikan pengertian mengenai konsep partisipasi. Jika ditinjau dari kata, "participation" berasal dari bahasa inggris yang artinya ambil bagian atau ikut serta. Berdasarkan penuturan Slamet (2017) partisipasi itu berarti peran serta secara aktif oleh seseorang atau kelompok mulai dari proses perumusan kebutuhan, perencanaan, hingga tahap pelaksanaan kegiatan baik melelui pikiran atau langsung dalam bentuk fisik. 
Menurut Dwiyanto (2011), partisipasi masyarakat diartikan sebagai keikutsertaan masyarakat kegiatan yang teridiri dari tahap persiapan, perencanaan, design, pelaksanaan maupun monitoring dan evaluasi. Keterlibatan tersebut dibagi menjadi beberapa bagian sesuai dengan keikutsertaannya. Kegiatan yang melibatkan masyarakat sebagai pendengar dalam suatu proses perencanaan, serta beberapa kegiatan yang meminta masyarakat memberikan masukan serta ada yang bahkan meminta masyarakat untuk memutuskan sendiri kegiatannya.

\section{c. Tingkat Partisipasi}

Delapan tingkatan partisipasi masyarakat menurut Arnstein (1969) adalah sebagai berikut :

a. Manipulasi; adalah tingkatan yang paling rendah dimana masyarakat hanya digunakan untuk memperoleh dukungan publik.

b. Terapi; artinya yang memgang kekuasaan berpura pura melibatkan masyarakat dengan memberikan alasan proposal.

c. Informasi; Pemegang kekuasaan tidak memberdayakan masyarakat dan hanya memberitahukan mengenai proposal kegiatan.

d. Konsultasi; Masyarakat tidak diundang dan tidak diberitahu untuk berbagi pendapat dan memberik masukan.

e. Penentraman; pemegang kekuasaan menunjuk sejumlah orang dari masyarakat yang berpengaruh untuk menjadi anggota badan publik serta mempunyai akses untuk pengambilan keputusan.

f. Kemitraan; Masyarakat berhak penuh berunding dan berpendapat dalam kesepakatan dan pengambilan keputusan.

g. Pendelegasian Kekuasaan; Masyarakat diberi kewenangan penuh untuk membuat keputusan dan rencana tertentu.

h. Kontrol Masyarakat; artinya masyarakat dapat ikut berpartisipasi untuk pengendalian proses pengambilan keputusan serta mengatur program yang berkaitan dengan kelembagaan.

\section{METODE PENELITIAN}

Rancangan kegiatan ini dimulai dengan mengurus perijinan untuk survei dan pengambilan data, setelah sudah didapatkan ijin dari instansi terkait maka dilanjutkan dengan survei dan pengambilan data. Langkah terakir dari kegiatan penelitian ini adalah mengolah data yang telah didapatkan selama survei dan pengambilan data tersebut.

Ruang lingkup dalam penelitian ini adalah di Kelurahan Wakung Kecamatan Reok, Kabupaten Manggarai. Administrasi Kelurahan Wangkung berbatasan langsung dengan : (Gambar 1)

$\begin{array}{ll}\text { Sebelah Utara } & \text { : Laut Flores } \\ \text { Sebelah Timur } & \text { : Desa Mata Air } \\ \text { Sebelah Selatan } & \text { : Desa Ruis } \\ \text { Sebelah Barat } & \text { : Desa Robek }\end{array}$

Teknik pengumpulan data pada penelitian ini adalah observasi, dokumentasi, serta wawancara

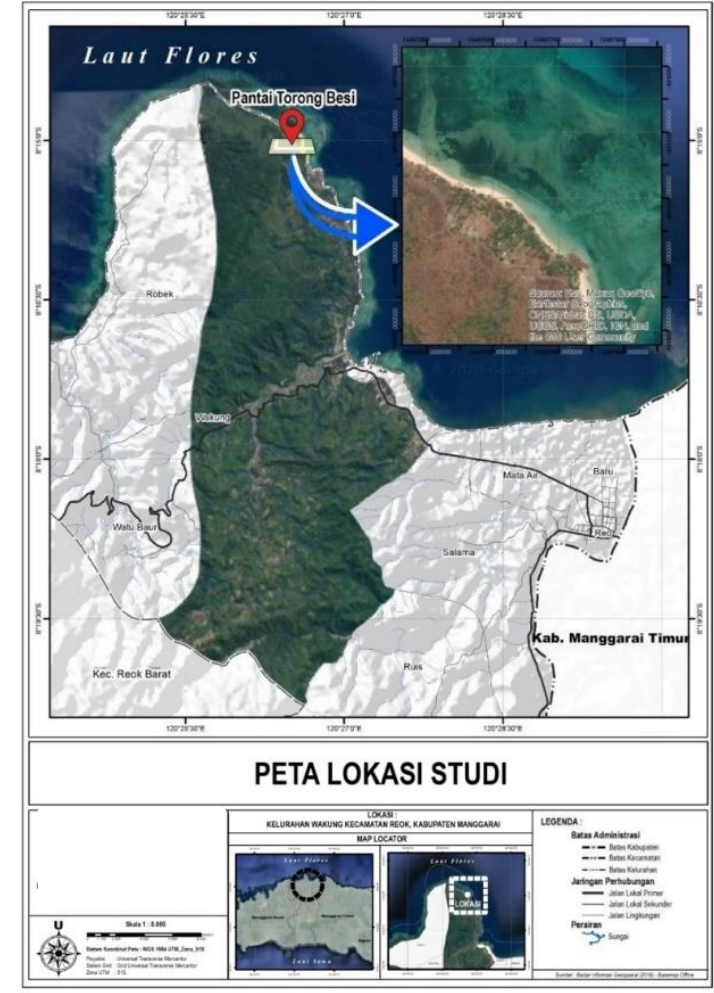

Sumber: Kompilasi, 2020

Gambar 1 Peta Lokasi Studi

Teknik analisis yang digunakan didalam 
penelitian ini adalah deskriptif kualitatif dan deskriptif kuantitatif menggunakan teknik persentase.

\section{HASIL DAN PEMBAHASAN}

\section{A. KARAKTERISTIK WISATA ALAM PANTAI TORONG BESI}

\section{Daya Tarik}

\section{a. Gua Maria}

Gua Maria Torong Besi adalah lubang besar bawah tanah yang telah ditata sedemikian rupa sebagai tempat patung Bunda Maria bertahta. Lokasinya yang berada di atas sebuah bukti di dekat jalur pantai utara (pantura), menambah eksotis pemadangan gua ini. Selain itu posisinya yang langsung menghadap laut membuat Gua Maria Pantai Torong Besi berbeda dengan gua yang lain. Gua maria menjadi salah satu daya tarik yang paling banyak dikunjungi oleh banyak orang untuk berziarah dan melakukan devosi kepada Bunda Maria, Pada bulan mei dan oktober.

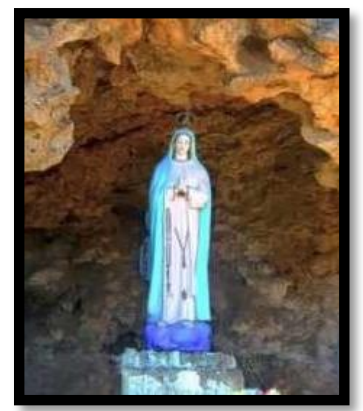

Sumber: Survei, 2020

Gambar. 2 Gua Maria

b. Gereja Tua

Gereja tua ini dibangun oleh seorang misionaris asal Belanda sebagai tempat ibadat umat katolik. Berdasarkan sejarah, gereja ini pada awalnya adalah tempat untuk pengungsian bagi para Pastor, Suster serta masyarakat lainnya pada masa penjajahan Belanda tahun 1949 serta merupakan titik pertama penyebaran agama khtolik di Kecamatan Reok. Gereja ini berdiri kokoh di bibir Pantai Torong Besi.

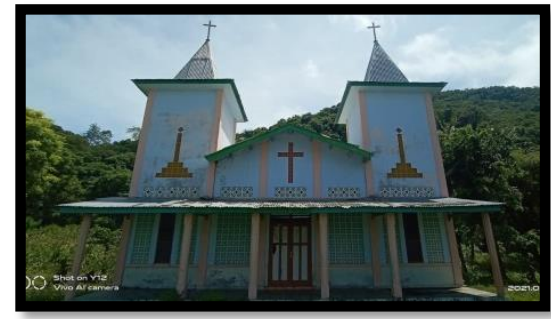

Sumber: Survei, 2020

Gambar. 3 Gereja Tua

c. Pasir Putih

Bagi masyarakat Kabupaten Manggarai, khususnya warga di Kecamatan Reok dan sekitarnya, Pantai Torong Besi tak lagi asing. Pantai berpasir putih nan elok ini, terletak di pesisir pantai utara (pantura) Pulau Flores. Pantai yang kelilingi gugusan perbukitan indah ini, merupakan salah satu objek wisata alam yang memikat hati.

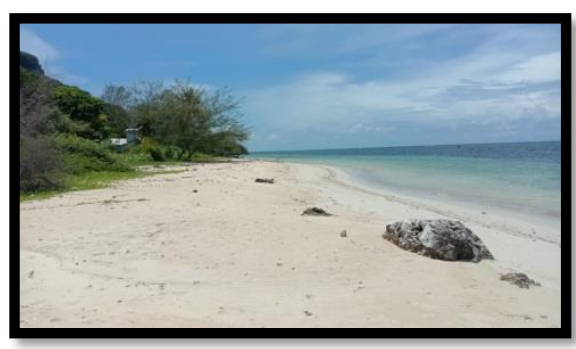

Sumber: Survei, 2020

Gambar. 4 Pasir Putih

\section{Aksesbilitas}

\section{a. Transportasi}

Untuk mencapai pantai torong besi, dapat ditempuh dengan menggunakan kendaraan pribadi baik roda dua maupun roda empat, atau menggunakan angkutan umum dari Kota Kecamatan. Waktu tempuh perjalan sekitar 15 menit. Untuk trayek angkutan kota, bisanya tersedia 2 kali dalam sehari yaitu pagi dan sore dengan rute Reok - Torong Besi dan Torong Besi - Reok. Berbeda jika perjalanan ditempuh dari Kota Ruteng yang merupakan Kota Kabupaten. Perjalanan akan memakan waktu kurang lebih 1,5 sampai 2 jam dengan menempuh jarak sejauh $62 \mathrm{Km}$. 


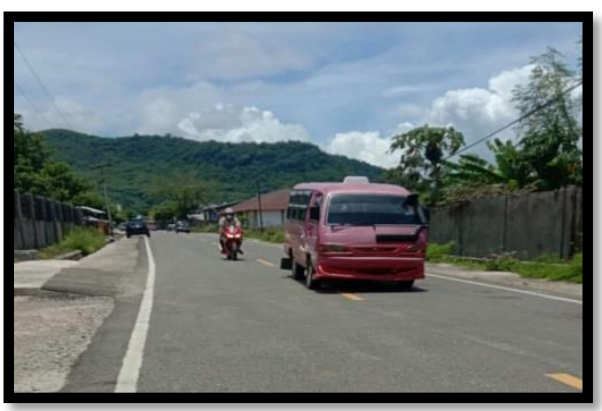

Sumber: Survei, 2020

\section{Gambar 5. Moda Transportasi}

\section{b. Jalan}

Kondisi jalan menuju obyek wisata pantai torong besi didominasi oleh jenis jalan yang perkerasaan aspal.. Jenis jalan ini yaitu jalan lokal sekunder dengan panjang $\pm 12 \mathrm{~km}$ dari ibu kota kecamatan. Lebar jalannya $5 \mathrm{~m}$ dan belum memenuhi standar jalan lokal sekunder.

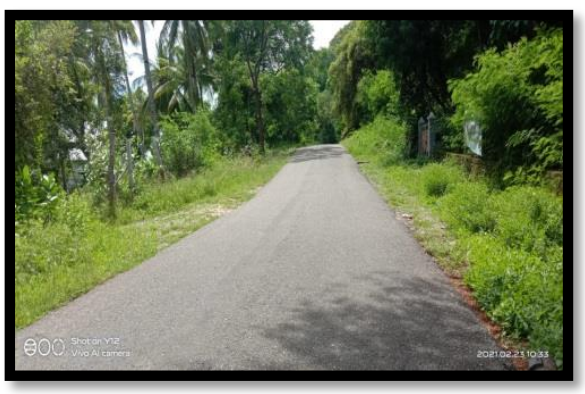

Sumber: Survei, 2020

\section{Gambar 6. Kondisi Jalan}

c. Terminal

Untuk mendukung aksesibilitas menuju obyek wisata pantai torong besi, tersedia juga terminal-terminal penumpang yang tersebar di beberapa titik. Namun hanya terminal kecamatan reo yang sering dipakai untuk menunjang aksesibilitas para pengunjung. Terminal di kecamatan reok merupakan terminal tipe $\mathrm{C}$, dimana terminal tipe $\mathrm{C}$ merupakan terminal yang terletak didalam wilayah kabupaten daerah tingkat II dan dalam jaringan trayek pedesaan.

d. Penunjuk Jalan

Untuk menuju lokasi Pantai Torong Besi wisatawan dapat dengan mudah untuk menemukan jalan, karena di sepanjang jalan sudah ada penunjuk jalan yang dapat memudahkan wisatawan untuk menuju pantai torong besi.

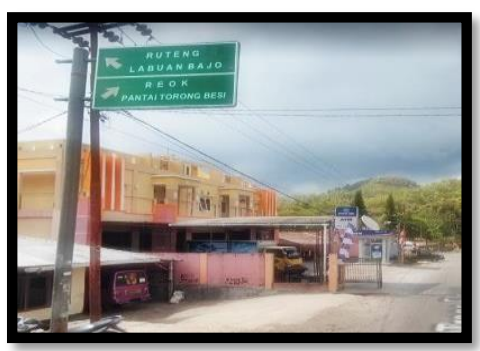

Sumber: Survei, 2020

\section{Gambar 7. Penunjuk Jalan}

\section{Fasilitas}

a. Akomodasi hotel

Akomodasi hotel yang terletak di kawasan Wisata Alam Pantai Torong Besi, hanya tersedia satu penginapan sederhana yakni homestay dengan fasilitas yang seadanya karena kebanyakan pengunjung adalah warga lokal dan tidak perlu menginap untuk bisa berkunjung ke Pantai Torong Besi. Jumlah pengunjung pada homestay ini pada tahun 2020 adalah sebanyak 73 orang. Jumlah kamar yang tersedia pada homestay tersebut berjumlah 10 kamar dengan fasilitas yang cukup memadai seperti, tv, kipas angin, serta kamar mandi dalam. Harga kamar untuk semalam dihargai sekitar 50.000/orang.

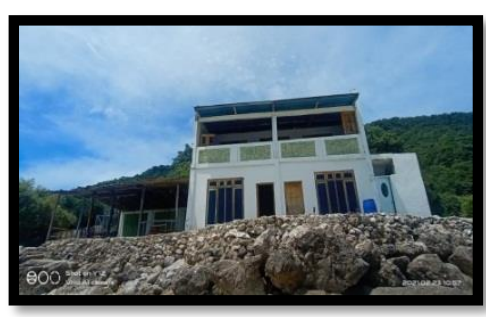

Sumber: Survei, 2020

Gambar 8. Akomodasi Hotel

\section{b. Restoran}

Pada kawasan objek wisata pantai torong besi belum tersedia restoran namun, hanya tersedia warung-warung kecil yang menu makanan sederhana. 


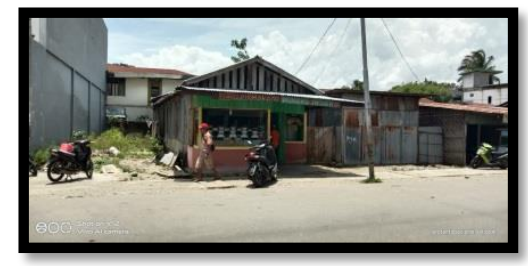

Sumber: Survei, 2020

\section{Gambar 9. Warung}

\section{c. Tempat Parkir}

Pantai torong besi sudah di sediakan lahan untuk tempat parkir bagi para wisatawan.Tempat parkir tersebut tersebar di beberapa titik di sekitar Pantai Torong Besi dan cukup untuk menampung kendaraan baik roda dua dan roda empat. Untuk memarkirkan kendaraan di tempat ini para pengunjung tidak di tarik biaya retribusi parkir. Hal ini dikarenakan lahan yang menjadi tempat parkir tersebut merupakan lahan kosong yang sengaja di fungsikan untuk parkiran.

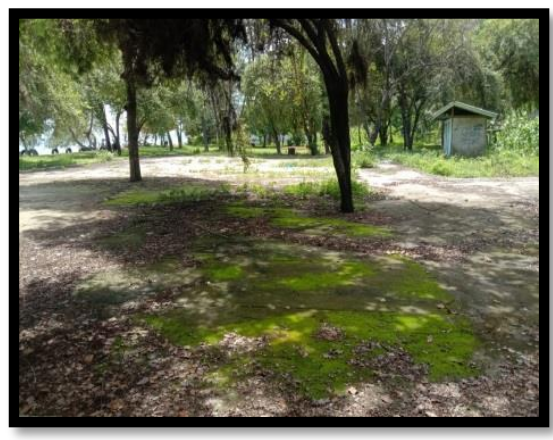

Sumber: Survei, 2020

\section{Gambar 10. Kondisi Tempat Parkir}

d. Tempat sampah

Tempat sampah sudah disediakan di pantai torong besi dan ada beberapa titik yang sudah di siapkan tempat sampah supaya pengunjung tidak membuang sampah sembarangan dan bisa menjaga kebersihan lingkungan di pantai tersebut. Pengelolaan sampah ditempat ini tidak diangkut menggunakan truk pengangkut sampah melainkan hanya dibakar.

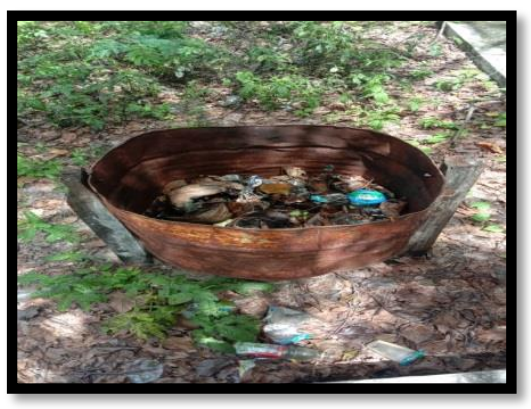

Sumber: Survei, 2020

\section{Gambar 11. Kondisi Tempat Sampah}

e. Tempat Ibadah

Tempat ibadah di pantai torong besi ada dua yaitu gereja dan gua maria. Dimana gereja dan gua maria menjadi salah satu alasan utama wisatawan yang beragama khatolik berkunjung ke pantai torong besi besi untuk beribadah.

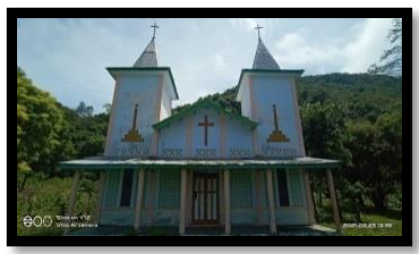

Sumber: Survei, 2020

\section{Gambar 12 Tempat Ibadah}

\section{f. Toilet}

Hanya terdapat satu toilet umum yang tersedia di kawasan objek wisata pantai torong besi. Sebenarnya bangunan toiletnya sudah cukup bagus dengan bangunan permanen dengan jenis closet duduk. Namun kondisinya cukup memprihatinkan karena kurang perawatan oleh pihak pengelola ataupun masyarakat lokal.

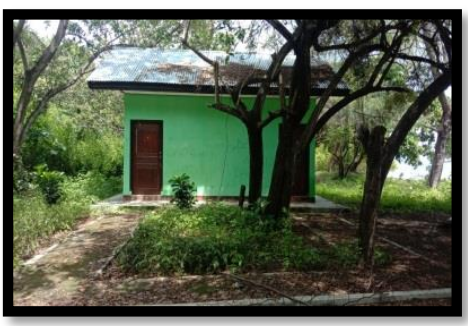

Sumber: Survei, 2020

Gambar 13 Kondisi Toilet 
B. TINGKAT PARTISIPASI

MASYARAKAT TERHADAP

KAWASAN WISATA PANTAI TORONG BESI

Guna mengetahui tingkat partisipasi masyarakat dalam mengelola tempat wisata di Pantai Torong Besi, maka penelitian ini melakukan analisis tingkat partisipasi (tabel 1)

Tabel 1. Kesimpulan Anasisis Tingkat Partisipasi

\begin{tabular}{|c|c|c|}
\hline No & Indikator & $\begin{array}{c}\text { Tingkat } \\
\text { Partisipasi }\end{array}$ \\
\hline 1. & $\begin{array}{c}\text { Partisipasi Masyarakat Dalam } \\
\text { Pengelolaan Gua Maria }\end{array}$ & Citizen Control \\
\hline 2. & $\begin{array}{c}\text { Partisipasi Masyarakat Dalam } \\
\text { Pengelolaan Gereja Tua }\end{array}$ & Citizen Control \\
\hline 3. & $\begin{array}{c}\text { Partisipasi Masyarakat Dalam } \\
\text { Pengelolaan Pasir Putih }\end{array}$ & Citizen Control \\
\hline 4. & $\begin{array}{l}\text { Partisipasi Masyarakat Dalam } \\
\text { Pengelolaan Akomodasi Hotel }\end{array}$ & Citizen Control \\
\hline 5. & $\begin{array}{c}\text { Partisipasi Masyarakat Dalam } \\
\text { Pengelolaan Restotan }\end{array}$ & Citizen Control \\
\hline 6. & $\begin{array}{c}\text { Partisipasi Masyarakat Dalam } \\
\text { Pengelolaan Tempat Parkir }\end{array}$ & Partnership \\
\hline 7. & $\begin{array}{l}\text { Partisipasi Masyarakat Dalam } \\
\text { Pengelolaan Tempat Sampah }\end{array}$ & Citizen Control \\
\hline 8. & $\begin{array}{l}\text { Partisipasi Masyarakat Dalam } \\
\text { Pengelolaan Tempat Ibadah }\end{array}$ & Citizen Control \\
\hline 9. & $\begin{array}{c}\text { Partisipasi Masyarakat Dalam } \\
\text { Pengelolaan Toilet }\end{array}$ & Citizen Control \\
\hline 10. & $\begin{array}{l}\text { Partisipasi Masyarakat Dalam } \\
\text { Pengelolaan Media Cetak }\end{array}$ & Informing \\
\hline 11. & $\begin{array}{c}\text { Partisipasi Masyarakat Dalam } \\
\text { Pengelolaan Media Online }\end{array}$ & Citizen Control \\
\hline
\end{tabular}

Sumber : Hasil Analisis, 2021

Berdasarkan Tabel 1 dapat diketahui bahwa tingkat partisipasi masyarakat dalam peningkatan kunjungan wisatawan Pantai Torong Besi didominasi pada tingkat citizen control dengan persentase sebesar $82 \%$. Hal ini dikarenakan masyarakat kelurahan wangkung memiliki pengetahuan mengenai pengelolaan kawasan wisata dan ikut berpartisipasi secara sukarela dan aktif dalam kegiatan pengelolaan dan pengembangan Wisata Pantai Torong.

\section{KESIMPULAN}

Berdasarkan hasil analisis diatas dapat ditarik kesimpulan sebagai berikut:

1. Karakteristik kawasan wisata Pantai Torong Besi yang terdiri dari :

a. Berdasarkan penjelasan daya tarik pada hasil analisis, diperoleh bahwa Wisata Pantai Torong Besi sudah layak untuk dijalankan mengingat wisata Pantai Torong Besi mempunyai daya tarik untuk menarik minat pengunjung yang terdiri dari beberapa objek seperti Gua Maria, Gereja Tua, dan Pasir Putih.

b. Secara keseluruhan aksesbilitas menuju Wisata Pantai Torong Besi sudah cukup baik. Namun ada beberapa yang belum memenuhi standar seperti kondisi jalan yang kurang baik serta jarak terminal dengan lokasi objek wisata yang terlalu jauh. Selain itu jumlah penujuk jalan yang masih terbatas yang bisa saja menyulitkan para pengunjung untuk menuju Objek Wisata Pantai Torong Besi.

c. Secara keseluruhan fasilitas yang terdapat di Objek Wisata Pantai Torong Besi sudah memadai. Hanya perlu adanya penambahan terkait jumlah hotel serta restoran atau rumah makan di sekitar lokasi Objek Wisata tersebut. Selain itu perlunya perbaikan pada fasilitas toilet.

d. Pelayanan tambahan di objek wisata pantai torong besi belum tersedia, karena pengelolaanya masih bergantung kepada masyarakat, serta belum ada partiispasi dari masyarakat setempat untuk pengelolaan pelayanan tambahan di Objek Wisata Pantai Torong Besi.

2. Berdasarkan tingkat partisipasi masyarakat dapat diketahui bahwa tingkat partisipasi masyarakat dalam peningkatan kunjungan wisatawan Pantai Torong Besi didominasi pada tingkat citizen control dengan 
persentase sebesar $82 \%$. Hal ini dikarenakan masyarkat kelurahan wangkung memiliki pengetahuan mengenai pengelolaan kawasan wisata dan secara sukarela aktif dalam kegiatan pengelolaan dan pengembangan.

\section{UCAPAN TERIMA KASIH}

Ucapan terima kasih dan penghargaan perlu penulis sampaikan kepada Tuhan Yang Maha Esa serta berbagai pihak yang telah memebrikan bantuan berupa bimbimbigan arahan ssaran, serta dukungan. Tidak lupa ucapan terima kasih kami sampaikan kepada orang tua, Kepada Pak Lurah Wangkung, Badan Pusat Statistika, yang telah membantu dalam memperoleh data.

\section{DAFTAR PUSTAKA}

Badan Pusat Statistik (2020). Kecamatan Reok Dalam Angka

Bareto dan Giantari, (2015), Strategi Pengembangan Objek Wisata Air Panas Di Desa Marobo, Kabupaten

Bobonaro, Timor Leste". Ekonomi dan Bisnis Universitas Udayana.

Larasati, D. C. (2019). Partisipasi Masyarakat Dalam Mengembangkan Taman Posyandu Sri Rejeki di Kelurahan Kotalama Kecamatan Kedungkandang. Jurnal Reformasi. Vol. 9 No. hlm 55-65

Raharjana (2016), Konsep Pengembangan Kawasan Desa Wisata Di Nagari Koto Hilalang, Kecamatan Kubung, Kabupaten Solok. Konferensi Nasional Ilmu Sosial \& Teknologi (KNiST),155-159. Diakses pada : http://seminar.bsi.ac.id/knist/indeks.p hp.knist/article

Riyani, E. (2018). Partispasi Masyarakat Dalam Pengembangan Obyek Wisata Alam Air Terjun Jumog Dan Dampak Terhadap Kondisi Ekonomi Masyarakat (Studi Di Desa Berjo Kecamatan Ngargoyoso Kabupaten Karanganyar Provinsi Jawa Tengah). Skripsi Fakultas Ekonomi Universitas Negeri Yogyakarta
Suwena \& Widyatmaja, (2017), Pengetahuan Dasar Ilmu Pariwisata. Bali : Pustaka Larasan

Sugiyono. (2015). Metode Penelitian Kuantitatif, Kualitatif dan $R \& D$. Bandung : CV. Alfabeta

Sugiyono. (2016). Metode Penelitian Kuantitatif, Kualitatif dan $R \& D$. Bandung : CV. Alfabeta 